\title{
A Reconsideration of the English Sources of La coronación de la señora Gracisla
}

\section{Una reconsideración de las fuentes inglesas de La coronación de la señora Gracisla}

\author{
JOSEPH J. GWARA \\ U. S. Naval Academy \\ gwara@usna.edu
}

In response to a study by Louise M. Haywood, Joseph J. Gwara challenges her interpretation of $L a$ coronación de la señora Gracisla, an anonymous work discovered in 1976, as a defense of Catherine of Aragon's virginity and hence an implicit justification for her second marriage to Henry VIII of England. Rejecting this hypothesis, Gwara attributes the work to Juan de Flores, viewing it as a juvenile divertissement written c. 1475 to celebrate the engagement of Leonor de Acuña and Pedro Alvarez Osorio, both members of the Castilian aristocratic elite. This interpretation of Gracisla is based on a detailed analysis of stylistic, codicological, genealogical, and historical evidence.

Palabras clave: La coronación de la señora Gracisla, Juan de Flores, Catalina de Aragón, Enrique VIII de Inglaterra, Leonor de Acuña, Pedro Alvarez Osorio

En respuesta a un estudio de Louise M. Haywood, Joseph J. Gwara pone en duda la interpretación de La coronación de la señora Gracisla, obra anónima descubierta en 1976, como una defensa de la virginidad de Catalina de Aragón y por lo tanto una justificación implícita de su segundo matrimonio con Enrique VIII de Inglaterra. Descartando esta hipótesis, Gwara le atribuye la obra a Juan de Flores, considerándola un divertissement juvenil compuesto circa 1475 para celebrar los esponsales de Leonor de Acuña y Pedro Alvarez Osorio, dos jóvenes de la alta aristocracia castellana. Esta interpretación de Gracisla está basada en un minucioso análisis de datos estilísticos, codicológicos, genealógicos e históricos.

KEYwORDs: La coronación de la señora Gracisla, Juan de Flores, Catherine of Aragon, Henry VIII of England, Leonor de Acuña, Pedro Alvarez Osorio

\section{INTRODUCTION}

$\mathrm{I}$

n a pair of recently published articles ("A New Epithalamial Allegory" and "Another Work"), I argued that La coronación de la señora Gracisla, an anonymous courtly work discovered in 1976, was written by Juan de 
Flores in celebration of the engagement of Leonor de Acuña (the eldest daughter of Juan de Acuña y de Portugal, III Conde and II Duque de Valencia de don Juan) and Pedro Álvarez Osorio, II Marqués de Astorga and III Conde de Trastámara y de Villalobos. On the basis of internal and external evidence, I maintained that Gracisla was composed as a divertissement for doña Leonor, who was probably between six and ten years old, and that its juvenile audience best explains its simple style. I also concluded that the work was written in the spring of 1475, when historical events closely paralleled the circumstances of the narrative, and that it was intended for public performance, probably with puppets, that same summer. Secondarily, I identified a subtle dynastic message in the work that celebrates the achievements of the Acuña family in Castile while reminding them of their responsibilities to the crown during a period of civil strife. In advancing these arguments, I rejected as untenable Keith Whinnom's view, elaborated in the introduction to his edition (Dos opúsculos), that Gracisla is broadly based on Henry VII's abortive attempt to marry Juana de Aragón, niece of Fernando de Aragón, between 1503 and 1506. As I explained, the circumstances of this proposed marriage differ considerably from the details of the narrative, and the historical parallels Whinnom identified are inexact, exaggerated, or, indeed, nonexistent.

Despite my objections, Whinnom's hypotheses received unexpected support in a recent study by Louise M. Haywood ("The Princess"). ${ }^{1}$ Although Haywood accepts my conclusion that Gracisla exhibits typical features of Flores's style $(195,202)$, she prefers to ascribe them to an imitator of Flores instead of Flores himself. Building on Whinnom's suggestion that the work's fictional court celebrations were based on the public festivities held in London for Catherine of Aragon in November 1501, she maintains that Gracisla was conceived as a "fictional test of Catherine's virginity" (200). As Haywood sees it, the widowed Catherine is portrayed as a virgin in order to dispel any doubts about the consummation of her marriage - one of many impediments to the negotiation of a new marriage contract after Arthur's death in April 1502 (199). Although this reading of the work, as Haywood admits (200), presents essential contradictions with the text, she dismisses them, arguing that the work broadly alludes to historical reality but makes no attempt to record it faithfully.

As I intend to show, however, this interpretation of Gracisla can no longer be sustained. Whinnom's English setting has no meaningful parallels with

\footnotetext{
${ }^{1}$ Haywood's article is a reworking of her "La coronación de la señora Gracisla and The Receyt of the Ladie Katheryne", presented at the Queen Mary and Westfield College Medieval Hispanic Research Seminar, Colloquium on Fifteenth-Century Literature, on June 26th, 1991.
} 
the text, while Haywood's claim that Gracisla was written by a master imitator of Flores is based more on expediency than a convincing reassessment of the evidence. Equally important, Haywood's hypotheses are founded upon an imperfect understanding of the circumstances surrounding Catherine's remarriage to Henry.

\section{Authorship}

As Haywood is aware, the attribution of Gracisla to Juan de Flores presents a major obstacle to her hypothesis that the work refers to Catherine of Aragon's disputed virginity. As I have demonstrated elsewhere, Flores was probably active as a writer in the mid-1470s, when he was a member of the ducal court of Alba ("The Identity", 105 n. 5, 217; "A New Epithalamial Allegory", 250251); the date of 1475 that I assigned to Gracisla conforms to this period. By contrast, Haywood's historical setting requires us to believe that the work was written between 2 April 1502, when Arthur died, and 23 June 1503, when Catherine was officially betrothed to his brother, Henry ("The Princess", 200). Since Flores was active twenty-five years before this time, his authorship would be improbable on chronological grounds alone. By the same token, if Flores actually wrote Gracisla, we would have to reject Haywood's proposed English setting, since it falls well beyond his most likely productive years. ${ }^{2}$

Not surprisingly, therefore, Haywood opposes my argument in favor of Flores's authorship of Gracisla, calling the issue "an open one" ("The Princess", 192). Although scholarly consensus will, indeed, ultimately decide the matter, Haywood's contribution to the debate contains several inaccuracies. She claims, for example, that I "concede" that "an enthusiastic imitator of Flores might have internalized aspects of his style and reproduced them in Gracisla" ("The Princess", 194). This remark, based on two isolated sentences from my original study ("Another Work", 79, 87), misrepresents my findings. Although I acknowledged, in the early stages of my argument, that Gracisla might be the work of an imitator, I went on to dismiss this hypothesis as counterintuitive and wrongheaded. As I put it, "there is a more persuasive interpretation of the evidence" ("Another Work", 79). After analyzing thirty pages of data, I concluded, with no room for doubt, that Flores himself must have written the work ("Another Work", 108). Yet, instead of refuting

\footnotetext{
${ }^{2}$ This argument also applies to Whinnom's proposed date of 1505-1506 (Dos opúsculos, XVII-XVIII).
} 
my argument, Haywood sidesteps it, implying that, as long as it is even remotely possible that an imitator could have written Gracisla, the case for Flores's authorship needs not to be addressed. However, these opposing viewpoints are not equally plausible. Why would an author, seeking to defend Catherine of Aragon's virginity in 1502, turn exclusively to Flores's works, written more than a generation earlier, for stylistic inspiration? Is it reasonable to conclude that the verbal echoes of Grimalte, Triunfo, Grisel, and the Crónica incompleta in Gracisla are the handiwork of an "enthusiastic imitator" of Flores instead of the rhetorical reflexes of Flores himself? If we acknowledge the existence of these echoes, how can we avoid taking the argument to its logical conclusion? Why is it so hard to believe that Flores wrote Gracisla?

Resistance to the attribution of anonymous works to known writers, especially those who have become literary icons, is a cliché of modern scholarship. Perhaps the most famous recent example of this phenomenon involves A Funeral Elegy, the Elizabethan poem signed by "W. S." and now attributed to William Shakespeare. For almost a decade, Donald W. Foster has maintained, against a tide of criticism, that the Elegy exhibits so many typical features of Shakespeare's style that it must be considered an original Shakespearean work. His latest contribution to the debate ("A Funeral Elegy") is an exceptional combination of literary sleuthing and old-fashioned hard work; in it, he makes the most convincing case yet for Shakespeare's authorship. Though Foster studies an English text written more than a century after Gracisla, his conclusions have a direct bearing on my own argument. He explains:

A Funeral Elegy belongs hereafter with Shakespeare's poems and plays, not because there is incontrovertible proof that the man Shakespeare wrote it (there is not) nor even because it is an aesthetically satisfying poem (it is not), but rather because it is formed from textual and linguistic fabric indistinguishable from that of canonical Shakespeare. Substantially strengthened by historical and intertextual evidence, that web is unlikely ever to come unraveled ("A Funeral Elegy", 1082).

These observations, coming from an expert in attribution criticism, provide a solid theoretical foundation for my conclusion that Gracisla must be accepted as an original work by Flores. In building the case for attribution, I analyzed, in minute detail, the stylistic features common to all of Flores's known writings. Comparing them to Gracisla, I found a remarkable degree of expressive uniformity. Having shown that Gracisla is "formed from textual and linguistic fabric indistinguishable from that of canonical" Flores and that this "web" is "substantially strengthened by historical and intertextual 
evidence", I concluded that the work must be assigned to his corpus. Indeed, to attribute a work in Flores's style to anyone other than Flores would require far more compelling evidence than the mere assertion that someone may have copied him.

The evidence supporting my argument is presented fully in "Another Work", and there is no reason to review it all here. ${ }^{3}$ However, three general comments are warranted. First, as Haywood acknowledges ("The Princess", 194), the case for Flores's authorship of Gracisla is incremental; it depends on an accumulation of evidence that must be evaluated in its entirety. A single stylistic parallel proves nothing, but dozens cannot be ignored. Hence, Haywood's criticism that "much" of my evidence is individually "inconclusive or coincidental" ("The Princess", 194) is inapplicable and misleading. Haywood also fails to realize that a few parallels, taken individually, are so striking that they corroborate our interpretation of all the others. Consider the following examples, whose importance I discussed in my original study ("Another Work", 86-87):

Gracisla: Pero con la mayor disimulación que pudo, fingió hun alegre riso en las partes de fuera... (5.11-12).

Grisel: la qual con vna falsa riza en las partes de fuera se mostro alegre... (Gwara, "A Study", 584).

Crónica: ... con mayor amor en el secreto del alma que en las partes de fuera mostrarlo podían... (Puyol, Crónica, 67-68).

Grimalte: más alegre en lo segreto que de fuera se mostrava... (Flores, Grimalte, 76).

It would be hard to argue that these parallels are merely coincidental. Combining conceptual consistency (dissimulation) and expressive flexibility (syntactic and lexical variation), they exhibit all the hallmarks of a phraseological signature. Unless we posit a complex series of intertextual borrowings, they must be seen as a genuine rhetorical reflex of Juan de Flores. I am confident that if scholars consider my evidence in its totality, they will perceive the strength of my argument.

Secondly, in attempting to refute my conclusion that Flores wrote Gracisla, Haywood overemphasizes the weakest evidence and downplays the strongest. She asserts, for example, that my case for authorship depends

${ }^{3}$ This article is a revised version of Chapter 1 of my doctoral thesis ("A Study"). 
"particularly" on "the plot motifs Gracisla shares with Grisel y Mirabella" ("The Princess", 194; also 192, 202). However, I made no attempt to establish Flores's authorship on this basis. Although some of the structural evidence - the use of a debate and an animal scene, for example - substantiated my argument, I focused mainly on the presence of stylistic parallels to confirm a prior deduction based on genealogical, codicological, chronological, and literary evidence. This circumstantial evidence, in particular, was essential to my argument, though Haywood relegates most of it to a footnote ("The Princess", 192 n. 3). In turn, she leaves several basic questions unanswered: Why does Gracisla allude to characters from Arnalte y Lucenda (1481 ad quem), but not Cárcel de Amor (1492)? Is it only coincidental that the name "Gracis$l a$ " is similar to the names that Flores usually gave his protagonists (Grimalte, 128 Gradisa, Grisel, Grisamón)? Why do Gracisla and Triunfo have the same ageneric character, blending romance and chronicle, the imaginary and the real, the sentimental and the ludic? $?^{4}$ Is it insignificant that both Flores and Gracis$l a$ 's author were fascinated by the conspicuous consumption of the Castilian aristocracy? Ignoring these questions, Haywood deals with only two substantive issues: style and codicological context. I respond to her comments below.

Finally, Haywood's rejection of my arguments entails several ironies. For example, she lists the Crónica incompleta under Flores's name in her 'Works Cited' ("The Princess", 203), tacitly accepting his authorship of this anonymous chronicle. She does not recognize, however, that the case for Flores's authorship of Gracisla is founded upon substantially the same methodology. To my knowledge, no one has challenged my identification of Flores as the author of the Crónica incompleta; some historians, in fact, have started to take the attribution seriously (e.g., Liss, Isabel, 377). Why is Haywood willing to believe that Flores wrote the Crónica incompleta, but not Gracisla? Furthermore, Haywood ("The Princess", 196) seems to accept Flores's authorship of Grisel y Mirabella without acknowledging the basis for this assumption. Nothing in the body of the work tells us Flores is the author, and the three extant manuscripts (Biblioteca Colombina MS 5-3-20, Biblioteca Trivulziana MS 940, and Biblioteca Apostolica Vaticana Vat. Lat. MS 6966) lack any such indication. ${ }^{5}$ In fact, the earliest ascription of Grisel to Flores is found in the Lérida

\footnotetext{
${ }^{4}$ Haywood later asserts that "[ $\left.t\right]$ he intermingling of characters with different degrees of fictionality as well as references to actual historic events and geographical locations is seen in many other texts, and is particularly prevalent in sentimental romances" ("The Princess", 196). Ironically, her most striking examples of this phenomenon are Flores's Grimalte and Grisel.

${ }^{5}$ On the Vatican manuscript, see Gwara and Wright ("A New Manuscript").
} 
incunable, which dates from ca. 1490-1495, nearly a generation after the time the romance was probably written. ${ }^{6}$ Since this attribution appears only in the title, the introductory rubric, and the printer's summary, only the flimsiest evidence links the romance to Flores. Why does Haywood confidently accept Flores's authorship of Grisel, based on this late and unreliable information, but reject his authorship of Gracisla, which has been substantiated with detailed textual analysis? What renders a printer's rubric more trustworthy evidence of authorship than consistency of style, form, and content?

To prove that Gracisla is the product of an "enthusiastic imitator" of Flores, Haywood must build her case on a cogent analysis of the evidence, not just assertion. She must explain why it is more reasonable to attribute a work with all the hallmarks of Flores's writings to an anonymous plagiarist of Flores and not Flores himself. She must show that an imitator actually existed who could - and wanted to- duplicate Flores's style with such precision that his product would be indistinguishable from canonical Flores. If such a man ever lived, his skill far surpassed that of the chivalric plagiarists, who copied long sections of Grimalte with virtually no alterations ("Another Work", 7879). Who was this master stylist, whose fictional test of Catherine of Aragon's virginity was also a silent tribute to Juan de Flores's expressive genius? Was he a secret admirer of Flores who, having read Triunfo, Grisel, Grimalte, and the Crónica incompleta, sought to replicate their author's rhetorical patterns, conventional names, preferred structural devices, and tendency to blend elements from different genres? Haywood never answers these questions on their own terms. Since the attribution of Gracisla to Flores undermines her most fundamental assumptions about the work's historical setting, she has no recourse but to reject my conclusions a priori and advance an interpretation of the evidence that defies common sense. Yet, if we set aside the preconception that Gracisla alludes to Catherine of Aragon's virginity —a highly dubious claim, as I intend to show - the identity of Haywood's mysterious master imitator of Juan de Flores becomes clear; he is Flores himself.

\section{THE CODEX}

In trying to rebut my argument for Flores's authorship of Gracisla, Haywood ("The Princess", 195) dismisses as "weak" my hypothesis that the codex to

\footnotetext{
${ }^{6}$ Since all later editions of the romance descend from this incunable, they offer no independent evidence of the author's identity.
}

Medievalia 50, 2018, pp. 123-157 
which the work originally belonged - now MSS 22018-22021 of the Biblioteca Nacional - was conceived as an anthology of works written by, or tacitly ascribed to, Flores ("A New Epithalamial Allegory", 229; "Another Work", 80-81). She begins by downplaying Harvey L. Sharrer's early attribution to Flores of the Tristan-Iseut letters in MS 22021 ("Letters"). Although she concedes that the evidence linking the Iseut letter to Flores is "strong", she asserts that the connection between him and the Tristan reply is "less convincing" ("The Princess", 195), apparently because Sharrer identified only one stylistic parallel with Grimalte ("Letters", 11-13). Haywood concludes: "It is possible then, but not probable, that the letters were included [in MS 22021] because of an association with Flores" ("The Princess", 195). Aside from failing to clarify what makes something "possible [...] but not probable", Haywood does 130 not seem to realize that Sharrer consulted only Grimalte for stylistic parallels; he made no effort to examine Flores's other works for corroborative evidence ("Letters", 14-15). Many years later, while pursuing this line of inquiry, I discovered significant verbal echoes of Grisel and the Crónica incompleta in both letters, thereby confirming the accuracy of Sharrer's original deduction ("A Study”, 115-117; “Another Work”, 98-99). For unknown reasons, Haywood fails to account for this new evidence, but one might justifiably conclude that the increased number of textual reminiscences would eliminate her cause for doubt and tip the balance from "possible" to "probable". More importantly, Haywood provides no evidence showing that the letters were written by two different authors, as her objection would have us presume. Sharrer himself rejected this possibility, arguing that both works share too many other features with Flores's canonical writings ("Letters", 14-15). In short, barring the discovery of additional evidence showing these stylistic parallels to be meaningless, we must conclude, pace Haywood, that the Tristan-Iseut letters are "probably" both original works by Flores.

With respect to the version of Arnalte y Lucenda in MS 22021, I maintained that an anonymous corrector attempted to link the work to Flores by inserting "Johan de" above "Sant Pedro" in the introductory rubric ("Another Work", 80-81). Haywood rejects my interpretation of this insertion, claiming that it is "less plausible" than the attribution to Flores of the Tristan-Iseut letters ("The Princess" 195). However, the evidentiary value of scribal additions and deletions cannot be dismissed so casually. Over ten years ago, I pointed out that the scribe of the Crónica incompleta mistakenly wrote "Juan de Flores" when copying a passage about "Juan de Robles" ("The Identity", 123124). This lapse, which Carmen Parrilla García also considered significant in the case for attribution ("Un cronista", 131), hinted at a silent link between 
author, text, and scribe. In my view, a similar phenomenon has occurred in MS 22021. Perceiving a connection between Arnalte — a work remarkably similar to Flores's love stories - and a writer vaguely remembered as "Johan de Fulano", the copyist attempted to correct an imperfect ascription. Although his effort was clumsy, the very presence of the words "Johan de" where one would expect "Diego de" is not insignificant, especially in light of the concentration of works by "Johan de Flores" in the codex. More importantly, Haywood herself provides no alternative explanation for this correction. If the copyist was not thinking of "Johan de Flores" when he altered this rubric, what was he doing? Was he simply trying to attribute the work to "Johan de Sant Pedro"?

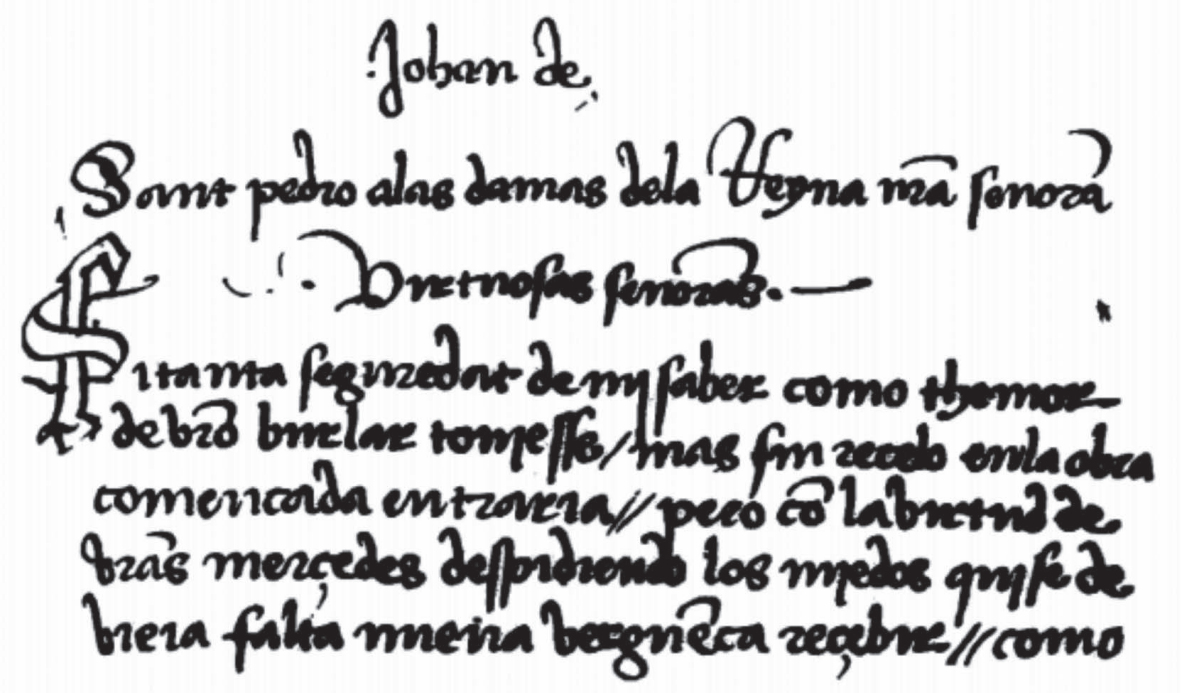

Biblioteca Nacional (Madrid) MS 22021, f. 13r

[Diego de San Pedro, Arnalte y Lucenda]

The scribe has altered the rubric to read "Johan de Saint Pedro" (note the carets after "de" and before "Sant Pedro"). Was he thinking of "Johan de Flores" when he made this correction, or was simply trying to attribute the work to "Johan de Saint Pedro"?

Of the eight texts in the codex, therefore, two (Grimalte and Triunfo) are indisputably by Flores, three (Gracisla and the Tristan-Iseut letters) have been attributed to Flores, and another (Arnalte) can be linked to Flores through an important scribal correction. The only texts lacking a documented connection with the sentimental writer are the two short letters exchanged by the "protonotario de Lucena" and Gómez Manrique. As I have shown, however, Manrique was a relative of Flores's patron, the duke of Alba ("Another Work", 
81). Perhaps Flores and Manrique were friends or literary associates; Flores may even have played a part —instigator, adviser, co-author, messenger - in the epistolary exchange. Lacking proof of Flores's direct involvement with either of these letters, however, I now prefer to view BNM MSS 22018-22021 as a collection of works by writers affiliated with the literary court of the first duke of Alba. With pride of place accorded to the works by (or perceived to be by) Flores, the Gracisla codex reflects the literary tastes of a single noble family. It may even have been compiled for the relatives of Garci Álvarez de Toledo in Aragón, thus explaining why the works of Flores, a Castilian, survive in manuscripts and printed editions with eastern linguistic and orthographic traits ("Another Work", 81). This hypothesis accounts for the importance of patronage in literary compilations, while moving away from vague and arguably anachronistic determinants like "letter form", "attention to court life", and "highly emotive content", which Haywood ("The Princess", 190, 202) prefers as thematic links. As a matter of fact, Gracisla has no "highly emotive content", and, though it has an epistolary frame, it contains no integrated letters like Arnalte and Grimalte. To describe the work as using "letter form", therefore, seems exaggerated. Moreover, Gracisla's emphasis on court life is primarily ceremonial and only secondarily sentimental - a feature it shares with Triunfo, but not with Arnalte and Grimalte. In short, Haywood's perceived thematic links are overgeneralizations that do not stand up to scrutiny.

\section{DATE}

The dates of composition of the codex's composite works also raise serious doubts about Haywood's proposed date for Gracisla. As I have already explained, Haywood claims the work must have been written between 2 April 1502 and 23 June 1503, a few years earlier than Whinnom's date of 1505-1506. Curiously, however, all other datable works in the codex -i.e., everything but the Tristan- Iseut letters - were written at least a generation before. I myself have argued that Triunfo de Amor dates from 1475-1476 ("The Date"). Grimalte y Gradissa, as Barbara Matulka pointed out (The Novels, 456-458), was already circulating by 1486 , though it, too, conceivably belongs to Flores's period of activity at Alba de Tormes. The Isabelline panegyric in Arnalte y Lucenda suggests a date around 1481 (San Pedro, Tractado, 46), although a primitive version of the work could have existed many years earlier. The carta consolatoria of the "protonotario de Lucena", together with Gómez Manrique's reply, must have been written shortly after Catalina Manrique's death, 
which Manuel Carrión places around October 1480 ("Gómez Manrique", 572). If, then, Gracisla was written in 1502-1503, as Haywood maintains, why was it copied alongside a series of courtly texts from the 1470s and 1480s? Haywood offers no convincing explanation for this incongruity. ${ }^{7}$ As I have argued, however, Gracisla was most likely written in the spring of 1475, a date that falls in line with the dates proposed for all the other texts in Gili's codex. In my view, these works were assembled in a single volume around 1500 for a patron interested in Juan de Flores's writings, probably because of some genealogical connection.

\section{STYLE}

In his literary appraisal of Gracisla, Whinnom faulted its style for being pedestrian, even mediocre (Dos opúsculos, xxxv). This harsh criticism was based on the assumption that the work was intended for an audience of adults. As I have argued, however, Gracisla should be understood as a rare example of juvenile literature. Written to entertain Leonor de Acuña on the occasion of her betrothal to the teenage Marquis of Astorga, the work was deliberately cast in a simple, direct language analogous to that of modern children's stories (Gwara, "A New Epithalamial Allegory", 240-241). In summarizing this important aspect of my argument, Haywood misrepresents my opinions in several ways. First, she claims that I discuss "Whinnom's view that the style is more simplistic than Flores's known writing” (“The Princess”, 194). This statement is incorrect. Whinnom never drew any explicit comparison between Gracisla's style and that of Juan de Flores; he simply observed that the style in the main body of the narrative was "bastante sencillo y directo" (Dos opúsculos, xxxv), a trait he preferred to ascribe to the author's inexperience or lack of talent. Evidently, Haywood tries to distance Gracisla from Flores by using the pejorative "simplistic", implying that the sentimental genius could not possibly

\footnotetext{
${ }^{7}$ Haywood seems to think that her date is strengthened by the fact that it is "closest to the date of the hand which copied the extant manuscript" ("The Princess", 200). However, this correlation proves nothing. Indeed, it could be argued that Haywood's proposed date falls dangerously close to the production date of Gili's codex, which Whinnom put at "hacia 1500" (Dos opúsculos, $\mathrm{x}$ ). Though my date of 1475 allows for copying at any time during the decade from 1495 to 1505 (as "hacia 1500" might imply), Haywood's unduly restricts the date of the hand to after 1502. Moreover, given the convergence of Gracisla's date of composition and the codex's date of production, are we to presume that Gracisla's composition occasioned the production of the entire codex? Haywood provides no evidence substantiating this hypothesis.
}

Medievalia 50, 2018, pp. 123-157 
have written a simple work. Yet, nothing about Gracisla is incompatible with Flores's writings. Fifteen years ago, no one could have guessed that the author of Grisel and Grimalte also produced the Crónica incompleta - a work whose style differs considerably from Flores's sentimental norm. Indeed, the discovery of the Crónica incompleta led to the realization that Flores, like San Pedro, was capable of adapting his writing to the demands of his audience. No stretch of the imagination is required to think that Flores could have composed a simple work for a young girl, especially if commissioned to do so. Equally important, Haywood fails to realize that Whinnom actually considered Flores a poor writer. Referring to Triunfo, he once commented: "[the work] is written in a florid style which frequently flounders in its own complexity, it is excessively repetitious and consists largely of a tissue of common places, and 134 it does little to clarify Flores's position in the feminist debate..." ("Review", 61; my italics). Ironically, these sentiments echo Whinnom's criticism of Gracisla's epistolary frame, where Flores's adult voice asserts itself:

tan pronto como empieza a intentar imitar el estilo elevado de un Diego de San Pedro, como en las cartas (caps 1, 2 y 20), se echa de ver su torpeza, pues le falta el sentido del ritmo de la prosa, carece de un adecuado dominio de la sinonimia y se enreda en complicadas frases de las que no siempre consigue escapar con éxito. (Dos opúsculos, xxxv; my italics).

Unintentionally, then, Whinnom himself identified an important stylistic trait linking Triunfo and Gracisla: their syntactic awkwardness (Gwara, "Another Work", 107-108). This common feature, together with Flores's versatility, leads me to dismiss as untenable Haywood's argument that Flores could not have written Gracisla because of some ill-defined "difference in the quality of the writing" ("The Princess", 195). ${ }^{8}$

Secondly, although Haywood acknowledges that my reading of Gracisla as a juvenile work is "intriguing", she adds that it "might be more convincing were [I] to bring forward further examples of such texts" ("The Princess", 195). This demand is unrealistic. As I originally concluded ("A New Epithalamial Allegory", 241), Gracisla appears to be the first nondidactic children's

\footnotetext{
${ }^{8}$ Ironically, Haywood fails to realize that an earlier generation of critics once dismissed the Pasión trobada as unworthy of San Pedro's genius - a bias Whinnom had to overcome (San Pedro, Poesías, 9-10). Before passing judgment on Gracisla's literary quality, therefore, Haywood should acknowledge that such criticism often says more about the prejudices of an age than the true artistic value of a work.
} 
work in Spanish literature; as such, it is a unique document ("A New Epithalamial Allegory", 254 n. 16). As Haywood is aware, it would be impossible, under these circumstances, to "bring forward further examples of such texts". By the same token, however, no one could reasonably expect scholars to substantiate their interpretations of unique works by adducing texts of similar character and style. Were this the case, criticism of the Libro de buen amor, Celestina, and myriad other early works would come to an abrupt halt. Ironically, though, the best way to expose the specious logic behind Haywood's objection is to apply it to her own argument. Can Haywood substantiate her reading of Gracisla by bringing forward other fictional defenses of Catherine of Aragon's virginity? Since she cannot, we should, by her own reasoning, reject her views as less than convincing.

Thirdly, Haywood asserts that I attribute Gracisla's stylistic simplicity to the use of allegorical techniques deriving from "the genre of the coronación" ("The Princess", 194). This statement is incorrect. As I explained, "certain episodes like the coronation of Gracisla by Fortuna and Fama reveal a debt to the traditions of medieval allegory, especially the coronación" ("Another Work", 82 ), adding that the coronación is "one of the few medieval genres whose works are commonly dedicated to children" ("A New Epithalamial Allegory", 241). I never alleged that Gracisla's style owes anything to the coronación; I merely suggested that the genre provided a familiar model for the allegorical coronation of a child. Indeed, in terms of style, Gracisla has nothing in common with the complex allegories by Francisco Imperial and Ruy Páez de Ribera, which Haywood adduces to refute my argument (“The Princess", 195). ${ }^{9}$ These poems were written for an audience of adults in honor of an infant prince; Gracisla, by contrast, was written for an audience of children in honor of one of their peers. By drawing a false analogy between a work dedicated to children (but not intended for their enjoyment) and one written expressly for children's amusement, Haywood reveals a fundamental misunderstanding of my argument. Indeed, as I see it, Gracisla incorporates some basic allegorical features of the coronación (a genre traditionally used for juvenile homages) but was conceived, first and foremost, as a childhood divertissement. This innovation accords with Flores's tendency to experiment with generic conventions.

Finally, aside from these basic misunderstandings, it is disconcerting to observe that Haywood quickly dismisses my explanation for Gracisla's stylistic

9 The same cancionero (PN1) contains similar works in honor of the infant prince Juan, including Fray Diego de Valencia's respuesta to Imperial's allegory, a dezir by Fray Bartolomé García de Córdoba, and another anonymous dezir (Dutton, El cancionero, 162-166).

Medievalia 50, 2018, pp. 123-157 
simplicity but offers no convincing alternative explanation for it. She claims, for example, that "the overuse of some of Flores's favourite brevity and inexpressibility topoi $[. .$.$] can be plausibly attributed to an imitator's response to$ various features of Flores's style, whether under pressure to meet a commission date or otherwise" ("The Princess", 195). However, since I have shown that Flores's style is characterized by an abundance of brevitas and inexpressibility formulas ("Another Work", 107), the profusion of such conventions in Gracisla is a reliable indicator of his very authorship of the work. Moreover, the notion that Gracisla's structural and stylistic anomalies could be attributed to an imitator's haste proves nothing; I myself argued that Flores himself probably wrote Gracisla in haste, perhaps to meet a commission deadline ("Another Work", 77). In short, none of these counterarguments adequately explains 136 Gracisla's unusual style. Like Whinnom, Haywood simply expects us to believe that Gracisla is the work of a talentless hack.

\section{The Court Celebrations}

Whinnom originally argued that the court celebrations depicted in Gracisla were based on two sets of public festivities held in London in November 1501 to honor the marriage of Catherine of Aragon and Arthur Tudor (Dos opúsculos, xxv, xxx-xxxiv). The first of these spectacles comprised a series of six tableaux vivants or 'pageants' commissioned by the City of London to celebrate Catherine's royal entry on November 12. The second, lasting the entire week of November 18-25, included a tournament and four banquets commemorating the royal nuptials. ${ }^{10}$ In the introduction to his edition, Whinnom provided a summary description of these lavish celebrations (Dos opúsculos, xxxi-xxxiv), concluding:

Está claro que las fiestas de Gracisla no corresponden exactamente con las inglesas de 1501 y que en nuestro cuento se encuentran detalles que parecen haber sido recogidos de otras fiestas anteriores, tanto inglesas como borgoñonas. No me hago ilusiones de haber demostrado — ni mucho menos - que entre otros muchos españoles que asistieron a las fiestas de Londres de 1501 estuviese nuestro autor. Sin embargo, es de notar que en la recepción de la princesa española constan todos los detalles esenciales de las fiestas de París (menos el mismo concurso): el torneo, el castillo, los cuadros vivos, los versos en elogio

${ }^{10}$ These festivities ended with a day of religious observances, gaming, and a mummery on November 28. 
de la heroína, los banquetes, bailes, músicos y acróbatas, sin contar la rueda de la Fortuna, los gigantes, el simulacro de combate, etcétera. Tampoco he logrado hallar otras festividades ni tan parecidas a las descritas en Gracisla ni de una fecha tan aproximada (xxxiv).

As we can see, Whinnom linked Gracisla to the London spectacles primarily on the basis of negative evidence. Since he was unable to identify any contemporary European festivities that exactly matched the fictional fiestas, he opted for the setting with the fewest discrepancies. This approach led him to emphasize a handful of broad parallels — a castle, mock battle, laudatory verses, banquets, jousts, dances, acrobats, and musicians - while ignoring or downplaying countless other details. By themselves, however, Whinnom's parallels are too vague to have any evidentiary value. As Whinnom observed, jousts, banquets, dances, music, acrobatics, and even miniature castles formed part of many aristocratic entertainments in fifteenth-century Europe (Dos opúsculos, xvii-xviii). Gracisla and Catherine's pageants arguably share no more features than could be adduced between any two medieval court spectacles. More importantly, the very details Whinnom suppressed conceal fundamental differences between Gracisla and the London celebrations. As I shall demonstrate, these real differences do more to undermine Whinnom's argument than any alleged parallels do to support it.

In the definitive study of Catherine's 1501 London entry, Sydney Anglo ("The London Pageants") describes the civic pageants as a series of dramatized allegories performed on lavishly decorated open stages. Built to resemble castles or temples, these stages were placed along the city streets between London Bridge and St. Paul's churchyard. As the royal couple and their entourage made their way through the city, they stopped at each tableau to listen to actors, dressed as historical, biblical, or allegorical figures, recite a complex poetic script celebrating their marriage. By linking the names of stars or constellations to the royal couple, the poet tried to show that the forthcoming union would bring honor to the individual spouses and, ultimately, the English monarchy. He also predicted, ironically, a glorious future for their reign. In conjunction with the verse's astrological imagery, the pageants' decorative scheme incorporated cosmological motifs. For instance, the fourth tableau, representing the 'Sphere of the Sun', was outfitted with a crude mechanical cosmos powered by a human treadmill; the third, the 'Sphere of the Moon', incorporated a stationary volvell, or astrological wheel. An array of English heraldic devices complemented this astral decor.

According to my own analysis, these tableauxand the fictional celebrations 
in Gracisla share only a few details, all of which are commonplaces of court festivities: ornate stages in the form of castles, brightly colored curtains and armorial banners, decorated thrones, and actors who recite poetry. As I discuss below, Castilian precedents exist for all these features. More importantly, the differences between the historical and fictional fiestas far outnumber the similarities. The Spanish text, for example, exhibits none of the cosmological symbolism or heraldic decor that characterized the English spectacles. In the London pageants, moreover, Catherine is addressed by religious, historical, and allegorical figures (Fronesis, Honor, Noblesse, Policy, Prelacy, Virtue, Alfonso X, Job, the Archangel Raphael, Boethius, St. Catherine, St. Ursula, and the 'Father of Heaven'), whereas the characters who praise Gracisla come from medieval romance or classical mythology: Grimalte, Diana, Minerva, Gradisa, Polidamas, Daries, Arnalte, Mirabel, Risel, etc. ${ }^{11}$ With its layers of recondite allusions, the English poetry is altogether unlike the Spanish arte mayor, which celebrates female beauty in simple, direct terms. Indeed, all the distinctive decorative and architectural elements of the pageants - the representation of the Trinity, images of the garter, crowned union roses, royal beasts (peacocks, lions, dragons, harts, greyhounds), golden portcullises, imitation marble pillars, heraldic emblems and badges, spiral moldings of alternating colors, angel choirs, seven candlesticks of the Apocalypse, zodiacal volvell, and mechanical cosmos - have no parallels in Gracisla. On the most basic conceptual level, then, it is hard to believe that Catherine's tableaux had any impact on the sets for Ricardo's joust and Gracisla's sala. If the English pageants had inspired the Spanish author, why would he have failed to refer to these predominant cosmological and heraldic motifs?

Perhaps aware of the vagaries of his argument, Whinnom tried to establish more specific links between Gracisla and Catherine's civic reception. In some cases - the "clouds" in the fourth pageant and the "nubes" in Gracisla's sala (Dos opúsculos, xxxii) — the parallels are trivial and arguably coincidental. ${ }^{12}$ In other instances, Whinnom overstates his case. For example, no necessary connection exists between the zodiacal wheel in Catherine's four-

${ }^{11}$ Whinnom argued that the character Úrsola in Gracisla must be St. Ursula, the English martyr who speaks in Catherine's first tableau. However, it is far more likely, in my opinion, that Úrsola - like Seringa, Remediaflor, Valentina, Virginea, etc. - is just another fictional name from an unidentified source.

${ }^{12}$ It is unclear whether these English "clouds" are veils or painted images. The "nubes" at Gracisla's sala (17.53-54) seem to be sheer drapes. The veils streaming from Ricardo's parade helmet are also described as "nubes" (9.15), which Whinnom glossed as "una especie de pañuelo muy ligero” (Dos opúsculos, 77 n. 30). 
th tableau and the wheel of Fortune in Gracisla. Despite the fact that most medieval representations of wheels derive from similar cosmological models (Anglo, "The London Pageants", 73, 87; Patch, The Goddess Fortuna, 76-78, 147), the specific connection made by Whinnom depends more on the ambiguity of the image than on any demonstrable parallels in concept or design. As Anglo describes it ("The London Pageants", 72), the London wheel was a primitive rotating cosmos, with stars and other astrological symbols moving under and around a central image of Arthur seated on a golden throne. With references to the Sun of Justice, Hesperus, the Lion of Judah, and Arcturus, the spectacle was conceived as a type of "solar apotheosis" in which Arthur is presented as "Christ the Redeemer" and "Christ the Sun of Justice" (Anglo, "The London Pageants", 76). By contrast, Gracisla employs the standard image of Fortune's wheel. The winner of the beauty pageant is to be enthroned at its pinnacle in recognition of her dual victory over her opponents and Fortune herself. Other than their basic shape, these wheels have nothing in common. The fact that they both rotate is far less significant than Whinnom alleged (Dos opúsculos, xxxi). As I discuss below, the wheel of Fortune was a frequent iconographical motif in fifteenth-century jousts, and Castilian texts actually refer to lifesize rotating models of it. In my opinion, Gracisla's wheel of Fortune was most likely based on a mechanical wheel the author saw at a contemporary tournament or on a written description of such a device.

In other instances, Whinnom's explanation of a possible parallel seems unnecessarily complex, even contrived. With respect to the puppet show at Gracisla's sala, he asks:

¿a qué viene, en medio de la representación de la destrucción de Troya, la historia de Jasón y la búsqueda del vellocino de oro $(17,36-53)$ ? Pues bien, la historia de Jasón era un tema predilecto de los autores de mascaradas del siglo xv y del Renacimiento, pero solo por su conexión con la Orden del Toisón de Oro, fundada en Borgoña en 1429 por Felipe el Bueno. [...] ¿ No parece probable que nuestro autor hubiese visto $\mathrm{u}$ oído hablar de tal cuadro sin llegar a apreciar su verdadero significado, es decir, su conexión con el Toisón de Oro? (Dos opúsculos, xxv- xxvi).

Although it is true that Jason was a favorite subject for some Burgundian and English pageants because of his association with the Order of the Toison d'Or, it is misleading to conclude that all literary references to the Trojan hero necessarily have a pageant source. In fact, Catherine's London tableaux contain no allusions to Jason or the Order of the Toison d'Or — a significant flaw 
in Whinnom's argument. ${ }^{13}$ More importantly, Whinnom himself pointed out that most medieval authors were probably familiar with the legendary history of Troy through Guido delle Colonne's Historia destructionis Troiae, which was widely available in vernacular translations (Dos opúsculos, xxvi). He even suggested that Gracisla’s author knew Guido’s text (Dos opúsculos, 84 n. 78). Ironically, this conclusion, instead of corroborating Whinnom's argument, actually supports my contention that Flores wrote Gracisla. In Título XVII of the Crónica incompleta, Flores explains that, before the outbreak of civil war, Fernando and Isabel were cautious in their negotiations with the Marqués de Villena, fearing that any misstep could jeopardize the future stability of the monarchy. Their prudence is compared to that of Priam, who, according to legend, weighed the opinions of his counselors and sons before attacking the 140 Greeks (Puyol, Crónica, 153). The source of this allusion, as Flores himself declares, is "la corónica Troyana” — a vernacular version of Guido's Historia. ${ }^{14}$ Like many other writers, therefore, Flores knew Guido's work and drew upon it for a variety of images and analogues. In fact, as I have observed elsewhere ("Another Work", 102 n. 31), the image of Jason and the Golden Fleece appears throughout his fiction and must have been one of his favorite allusions. In my opinion, the Trojan puppet show is merely the ludic evocation of a legend that fascinated Flores —an interpretation that suits the celebratory tone of the work. By contrast, Whinnom's explanation, with its presumption of a pageant source and its delitescent reference to the Order of the Toison d'Or, is needlessly complex.

With respect to Arthur and Catherine's wedding tournament and banquets, Whinnom has likewise exaggerated their parallels with Gracisla. In addition to a magnificent tree of chivalry, the English tournament was distinguished by the use of extravagant pageant cars that conveyed the combatants into the lists (Anglo, Spectacle, 100-103). On November 18, for example, Sir William Courtenay arrived in a dragon-shaped wagon pulled by a giant; on November 24 , a team of combatants, disguised as sailors, entered aboard a ship to the roar of a cannonade; and on November 25, the challengers showed up in a pageant car of cloth of gold led by four courtiers dressed as lions, a hart, and an ibex (Anglo, Spectacle, 100-101). Pageant cars also constituted the

${ }^{13}$ Anglo (Spectacle, 187) points out that Jason makes his first appearance in an English royal entry in 1522, when Carlos V, head of the Order of the Toison d'Or, was welcomed to London. Though other classical heroes appear in fifteenth-century English festivities, Anglo adduces no references to Jason earlier than 1522 .

${ }^{14}$ Flores alludes to Book VI (Norris, "La coronica troyana”, 92-104). 
principal novelty at the wedding banquets. On November 21, one car, in the form of an arbor, carried the gentlemen in disguise, while another, an illuminated lantern of sheer fabric, concealed the ladies; on November 25, a more elaborate spectacle included two pageant cars in the shape of mountains, one lush and fertile, where the lords sang and played instruments, and the other scorched and barren, where the ladies engaged in similar entertainments; on November 28, three sea horses deployed a two-story pageant car carrying sixteen lords and ladies (Anglo, Spectacle, 101-102). The most ambitious pageant, on November 19, involved three cars: a castle, a ship, and a mountain, all imaginatively constructed and bearing courtiers in costume (Anglo, Spectacle, 102-103). Except for the latter pageant, which inaugurated the banquet series, the pageant cars functioned largely as sets in a stylized dance, with the lords and ladies promenading around them after dismounting.

A comparison of the London wedding tournament and Ricardo's joust in Gracisla uncovers no meaningful resemblances. The two most distinctive features of the English games - the tree of chivalry and the fanciful pageant cars - have no parallels in the fictional work, while all the other descriptive details exhibit fundamental differences. ${ }^{15}$ Instead of riding a pageant car, Ricardo enters the lists on horseback, surrounded by twenty-four children disguised as dwarfs, each carrying a scallop point extending from his mount's magnificent bard; between them walk twenty-four giants - perhaps courtiers on stilts - with a lance in each hand (8.17-30). During the second day of jousting, Ricardo is accompanied by a group of "moras negras", who sing and dance, and fifty wild-men, who engage in a mock joust atop "diformes bestias", much to the delight of the audience $(9.16,23)$. Aside from their grand scale, these two scenes share only one possible feature - a giant - though neither Whinnom nor Haywood explains how Sir William Courtney's lone giant inspired Ricardo's twenty-four lance-bearing “filisteos”. By the same token, the English banquets and disguisings have nothing in common with the fictional salas in Gracisla. Instead of a dance with pageant cars, the entertainments at Gracisla's sala include a quartet of singers accompanied by four

\footnotetext{
${ }^{15}$ The only possible reference to a pageant car in Gracisla is found in the description of Fama, who sits atop "unos carros de oro" $(10.19 ; 13.8)$ bearing the likenesses of famous men and women from the past. These "carros" are later referred to as a "trihunfo" (15-11), which Whinnom glossed as 'tribuna' or 'estrado,' without supporting documentation (Dos opúsculos, 82 n. 63). In my opinion, however, "triunfo" is a triumphal car or chariot identical to those found in manuscript illustrations of Petrarch's Trionfi (Shepard, The Lore, 72 and Plate VII). Despite being equipped with wheels, however, Fama's chariot never moves and cannot be considered a pageant car in the conventional sense.
} 
instrumentalists, torches that cast oddly colored shadows on the revelers' faces, and two pies containing fully armored dwarfs who, upon emerging, engage in a mock battle (17.14-35). These amusements are followed by the Trojan puppet show, a firebreathing dragon (possibly a line rocket), and a spectacular mummery (17.35-65). The similarities between these two events - food, dancing, music - are so vague that, by Whinnom's standard, virtually every Burgundian feast could have been a source for Gracisla. More importantly, Anglo (Spectacle, 101) concludes that the single most unusual feature of the royal banquets was the indoor use of pageant cars - a novelty with which Gracisla's author shows no familiarity. How could the Spanish author have based his fictional fiestas on these English pageants without referring to this remarkable innovation?

142 The inadequacies of the English wedding tournament as a source for Gracisla are also illustrated by two parallels that Haywood adduces in support of Whinnom's argument ("The Princess", 193). In her opinion, two scenes from Ricardo's joust derive from incidents that took place in the tilt-yard during the third day of the event. The first scene, according to the description in the Great Chronicle of London, reads: "Then Secundaryly Ran to guydyr my lord henry of Bukkyngham and therle of Essex Sundry coursys wyth sundry ffortunys, But the Erle dyd the lesse ffeatys, because his hors was not apt ffor to cope" (cit. in Haywood, "The Princess", 193). Haywood compares this scene with the following episode at Ricardo's joust:

Y Ricardo y Talaborte se encontraron los primeros golpes, y al ferir de los encuentros sallieron muchos truenos y relámpagos de fuego de la lança de Ricardo entre toda la gente, los quales venían tan sotilmente inventados que maravillosa cosa fue de mirar el grand plazer del pueblo, porque el sonido de los truenos fue muy grande, y el golpe ninguno, del encuentro. $Y$ el cavallo de Talaborte se espantó de tal manera que lo oviera de aver rastrado, y el de Ricardo ningún movimiento hizo, por lo aver algunos días ante usado. Y después vino Talabort en otro cavallo [...] (8.52-62).

In Gracisla, Talaborte's horse is frightened by an explosion apparently caused by a powder charge concealed in the tip of Ricardo's lance. The narrator does not explain why Talaborte's horse had to be replaced, but we are led to believe that the animal could not be calmed after the blast. In the Great Chronicle, by contrast, we are told that the Earl of Essex's mount could not compete with that of his rival, the Duke of Buckingham; the animal was simply inferior. Aside from horses, these two scenes have nothing in common. At the very least 
we might expect the Great Chronicle to refer to the explosion - the central feature in Gracisla - but this detail is never mentioned.

The second episode from the Great Chronicle is equally vague:

And then [the Chalengeours \& deffendors] Turneyed agayn In such wyse that where It was appoyntid by the Jugis [...] that eythir of theym shuld have smyttyn but xij strokis, They lykyd theyr Game soo well that they wold not dyssevyr tyll they were fforcid by the marchall \& his servauntis, And thus endid this Royall Justis to the Grete comffort of the beholders (cit. in Haywood, "The Princess", 193).

Haywood compares this incident to a scene from the second day of Ricardo's joust:

Pero Ricardo, como lo conoció, muy denodadamente puso las manos en él, y entre los otros golpes que le dio le ferió con uno en el braço del espada, y ge le fizo saltar de la mano. Y quando vio Ricardo a Talaborte sin espada, lançó muy lexos la suya y juntó con él; y de encima de los cavallos lucharon una grand pieça. Pero Ricardo tenía grand fuerça en los braços; sacóle fuera de la silla, y dio con él del cavallo en el suelo, de lo qual ovo el rrey grand enojo, y mandó a Ricardo y a los otros cavalleros que dexasen el torneo aquel día (9.31-40).

In the Great Chronicle, the knights become so engrossed in combat that the marshal of the tournament has to separate them by force. In Gracisla, however, Ricardo and Talaborte are engaged in hand-to-hand combat on horseback. After Ricardo throws Talaborte to the ground, the King of France, angered by the humiliation of his hand-picked champion, calls an abrupt end to the day's games. Contrary to Haywood's assertions, no feature from Gracisla has a direct parallel in the Great Chronicle. The latter source contains no mention of the casting aside of swords, the hand-to-hand combat, the unseating of an opponent, or the king's anger; indeed, the characters' motivations and actions are entirely different.

Nothing in either Whinnom's or Haywood's analysis leads me to believe that the London pageants for Catherine of Aragon have any connection with Gracisla. For this reason, I suggested that the fictional jousts and celebrations were based on the Valladolid tournament and sala of April 1475, which the Duke of Alba hosted for the Catholic Monarchs ("A New Epithalamial Allegory", 238-239). We know that Flores attended this lavish event, since he provides his own eye-witness description in Título $X X$ of the 
Crónica incompleta. Haywood, however, rejects this suggestion, claiming that this tournament and sala "do not contain any significantly overlapping details which might suggest direct allusion of [sic] the part of the author of Gracisla" ("The Princess", 193-194). This assertion is categorically incorrect. The Crónica incompleta and Ricardo's joust exhibit a number of parallels, several of which are arguably significant: the selection of jewels as prizes; the tilt-galleries constructed for the spectators; the sumptuous attire of the participants; the lavish horsebards of spun gold, "[de] oro tirante" (Puyol, Crónica, 166), just like Ricardo's "paramentos [...] de oro tirante fechos a nesgas” (8.20-21); pages sporting clever invenciones in their helmets, just like Gracisla's pages, who wear her two motes in pearls on their sleeves (18.1415, 17-18); a host of musical instruments; knights knocked from the saddle,

144 their helms and lances in splinters; jousting by flambeaux after sundown; and the Duke of Alba's sala later that evening, with momos "tan ricos y costosos, que, por temor de no ser creydos, me dexo de escreuir los grandes gastos que en estas fiestas hizo, non solo aquel dia y noche, mas toda aquella semana [...]" (Puyol, Crónica, 168). In spirit and style, these proceedings recall the fictional jousts and salas depicted in Gracisla. More importantly, nothing in Flores's chronistic account of the Valladolid tournament presents any essential contradiction with the spectacles described by Gracisla's narrator. It is conceivable, then, that the fictional narrative actually alludes to this celebrated historical event.

Although it is impossible to know what details Flores omitted from his description of the Valladolid joust, another source, the Cronicón de Valladolid, offers an important point of comparison. The chronicler, whose account of the April festivities is shorter than Flores's but no less fulsome, remarks: "[f] ue la más rica justa que se vido, segun dicen, cinquenta años avia” (Puyol, Crónica, 169). This is an obvious allusion to the Paso de la Fuerte Ventura, the first in a series of lavish tournaments sponsored by the Infantes de Aragón and Juan II in Valladolid in the spring of 1428. Francisco Rico ("Unas coplas") has reconstructed this tournament series, relying mainly on Pero Carrillo de Huete's eye-witness account in the Crónica del Halconero de Juan II (Mata Carriazo, Crónica, 20-26). For the inaugural joust, sponsored by the Infante don Enrique on May 18, the sets included a castle tower of timber and canvas with four turrets and, in the center, a bell-tower supporting a pillar with a gilt griffin holding a large red and white armorial standard. An inner defensive fence (cerca) with four turrets surrounded this structure, which, in turn, was encompassed by a slightly lower wall (barrera) with twelve turrets, each housing a lavishly attired maiden, perhaps a sculpture. An enormous golden 
wheel — the "Rueda de la Aventura" - was hung on the inner fence near the tower, and a decorated throne placed underneath. At the other end of the lists stood an arch flanked by two towers through which the combatants entered the tilt-yard; an inscription above the archway read: "Este es el arco del pasaje peligroso de la fuerte Ventura”. Atop each of the towers stood a man with a hunting-horn, ready to announce the arrival of the challengers. Prior to the joust, the Infante Enrique made a stunning entrance on an entremés featuring eight ladies on horseback and a pageant car with numerous minstrels, twelve singing damsels, and the goddess Fortuna, who, accompanied by her court, took her seat under her golden wheel. Among the aventureros that day was Juan II, who showed up with twenty-four retainers, all richly attired. Following the joust, the Infante Enrique treated the entire entourage to a grand banquet.

Even if we disregard the two subsequent tournaments, held on May 24 and June 6 and sponsored by the Infante don Juan and Juan II, respectively, the first tournament alone - with its timber castle, gilt griffin, lifelike statues of maidens, lavish costumes and horsebards, decorated throne, wheel of Fortune, banquets, musicians, dances, and primitive theatrics - offers ample historical precedent for the fictional celebrations described in Gracisla. If the comparison in the Cronicón de Valladolid can be trusted, then the Valladolid tournament of 1475 must have been conceived on an equally grand scale, perhaps with its own wheel of Fortune, wildmen, giants, dwarfs, Moorish dancing girls, etc. Contrary to Haywood's assertions, therefore, it is entirely plausible that Ricardo's joust was modeled on this latter celebration, even though the Crónica incompleta omits most of the particulars. At the same time, however, we cannot rule out the possibility that some of the details of Gracisla's fictional fiestas come from written sources, including literary works and contemporary chronicles. ${ }^{16}$ Rico ("Unas coplas", 523), for example, demonstrates that the Paso de la Fuerte Ventura was part of the collective memory of Castilians as late as 1476, when Manrique penned his Coplas. Was Flores also thinking of this tournament when he wrote Gracisla? Perhaps he had in mind the coronation festivities of Fernando de Antequera in 1414, which also featured a mechanical wheel of Fortune and allegorical floats (Stern, The Medieval Theater, 97-98). Whatever the case, Flores, as a royal chronicler, must have had access to reliable accounts of many famous events of this sort. ${ }^{17} \mathrm{He}$ may

\footnotetext{
${ }^{16}$ I myself identified París y Viana as one possible literary source ("Another Work", 88 n. 21).

${ }^{17}$ We now that Flores was a reader of chronicles. In the Crónica incompleta, he cites chronicles of Enrique IV, probably that of Enríquez del Castillo (Puyol, 48-50, 59, 168, 250, and
} 
also have been aware of lavish contemporary festivities like those sponsored by Miguel Lucas de Iranzo in Jaén throughout the 1460s (Stern, The Medieval Theater, 102-106).

Although a great deal of work remains to be done on Gracisla's sources, it is clear that Whinnom seriously underestimated the possible impact of native Iberian tournaments (Gwara, "A New Epithalamial Allegory", 238-239; Stern, The Medieval Theater, 259-260). Perhaps if he had known of the Valladolid joust - the last vestige of Castilian court ceremonial in the grand Burgundian style - he might have felt less confident about proposing an English source for Gracisla's fiestas. As it stands, however, his argument requires us to believe that an unknown writer, with unknowable linguistic skills, consulted unidentified sources to create a literary pastiche of unidentified European 146 tournaments, which remotely resemble, but in no way can be shown to derive from, the London festivities for Catherine of Aragon. Vague and diffuse, this hypothesis strains credulity. By contrast, I have suggested that Juan de Flores, an author with a documented interest in court festivities, attended the Valladolid joust of April 1475 — the single most extravagant event of its kind in Castile in fifty years - and incorporated details of his eyewitness experience in Gracisla. Uniting author, circumstance, opportunity, and motivation, this interpretation treats the work as a concrete cultural artifact, not just a boardgame for critical speculation. More importantly, my reading of Gracisla stands independently of my proposed source, whereas Whinnom's and Haywood's depend largely on the viability of their English setting. The rejection of Catherine's wedding feasts as a source for Gracisla thus effectively vitiates their interpretations of the work.

\section{INTERPRETATION}

In the opinions of Whinnom and Haywood, Gracisla broadly alludes to the attempts of Henry VII of England to form a political alliance with Castile by marrying into the ruling Trastamaran line. This conclusion is founded on the narrator's remarks that the fictive "rey de Inglaterra" harbored hopes of marrying the Castilian Gracisla $(17.82-84 ; 18.29)$. As Whinnom initially observed (Dos opúsculos, xiv), Henry VII had been negotiating a matrimonial

293), Juan II of Aragon (99), and Juan II of Castile (149, 293). Moreover, Titulo III contains an explicit reference to the "General Estoria" (76), from which Flores extracts the legend of Bernardo del Carpio. 
alliance with the Catholic Monarchs since 1488; his plans came to fruition only in 1501, with the ill-starred marriage of Catherine of Aragon and Arthur Tudor. However, Whinnom quickly dismissed the notion that the "rey de Inglaterra" and Gracisla might represent the Prince of Wales and Catherine: Arthur never ascended the English throne, Gracisla is not a princess, and the "rey de Inglaterra" is portrayed as an older man, who accompanies his niece Brianda to the Paris beauty pageant (Dos opúsculos, xiv-xv). For these reasons, Whinnom concluded that the "rey de Inglaterra" was most likely Henry VII himself, who, after the death of Elizabeth of York in December 1502, considered marrying one of at least five Spanish widows, including Catherine of Aragon, Juana la Loca, and Juana de Aragón, exiled queen of Naples. For Whinnom, the most likely candidate for Gracisla was Juana de Aragón. In June 1505, the English monarch dispatched three ambassadors to Valencia to examine her, and it was widely rumored in Spain that she would become the next English queen (Dos opúsculos, xv-xvi). In early 1506, however, Henry apparently abandoned his plans to marry doña Juana in favor of more attractive alliances elsewhere.

As in the case of Catherine's civic pageants, Whinnom identified Juana de Aragón as Gracisla's historical counterpart because her profile differed least from that of the fictional heroine (Dos opúsculos, xvi, xviii). As he himself admitted (Dos opúsculos, xxi), however, this identification is not problem-free. According to the narrator, for example, the "rey de Castilla" does not know and, indeed, is unrelated to Gracisla, despite the fact that Fernando el Católico, the fictive king's real-life alter ego, was Juana de Aragón's uncle (Dos opúsculos, xiii-xiv). The text also describes Gracisla as the daughter of a high-ranking nobleman $(4.18-19,4.34,4.64)$ —an implausible genealogy for the eldest daughter of Ferrant I of Naples by Juana de Aragón, Fernando el Católico's sister. In the text, moreover, Gracisla's father is living, though Ferrant I died in 1494, more than ten years before Whinnom believed Gracisla was written. Similarly, according to sources cited by Whinnom (Dos opúsculos, xx), Juana de Aragón was born in 1477 or 1478, making her a mature woman of almost thirty when Henry VII considered marrying her. The fictional Gracisla, however, is portrayed as a young maiden, still under her father's care. Finally, the author of Gracisla places great importance on the Spanish heroine's virginity, even to the point of inventing the unicorn hunt to dispel doubts about her victory at the beauty pageant. Doña Juana, by contrast, was a widow, and, though her marriage was probably not consummated, it seems unlikely that any writer would have equated her virtue with that of an unwed virgin. Although these discrepancies cast doubt on the argument that Gracisla might represent 
Juana de Aragón, Whinnom simply dismissed them, implying that the text itself was full of apparent errors and contradictions and that any inconsistencies could be viewed as authorial lapses or poetic license (Dos opúsculos, xxi-xxii).

In a review of Whinnom's edition, Nicholas G. Round ("Review") pointed out other serious problems with this identification. At the end of Gracisla, for example, the narrator boasts that the world's great beauties hail from Castile (19.10-11). Yet, if the work had been written for doña Juana, why would the author not ascribe this legendary status to Aragon, her homeland? The narrator's remark would only make sense if Gracisla's historical counterpart were Castilian. Equally disconcerting in Round's view is the fact that the "rey de Castilla", upon first seeing Gracisla, voices regret that he cannot marry her since he had already taken a wife. According to Whinnom's scenario, Fernando el Católico appears to lament his inability to marry his own niece. Even Fernando's well-known sexual excesses fail to explain the jarring indiscretion of this comment.

In an attempt to resolve some of these discrepancies, Round suggested that Gracisla might represent Juana la Loca, a renowned Castilian beauty ("Review", 333). ${ }^{18}$ Since Fernando could not possibly have married her, the remark of the "rey de Castilla" could be interpreted as a "far-fetched compliment to a daughter" ("Review”, 333). Gracisla's unicorn, moreover, could be understood as a symbol of Felipe I, whose early death contributed to Juana's fabled dementia. Round also speculated that Gracisla's post-coronation motto - "Sin temor de Fortuna" - could be read as an expression of hope for a happy future following her premature widowhood. Amidst these conjectures, however, Round failed to explain why Juana la Loca would be portrayed as the daughter of a nobleman and why she would be unrelated to the "rey de Castilla". In addition, the notion that Fernando would praise his own daughter by proposing an incestuous marriage strains credulity, while nothing in the text suggests that Gracisla's unicorn is anything other than a routine animal image intended to affirm the judges' disputed decision and, indirectly, the winner's virginity. Round's argument, like Whinnom's, can only be accepted if we ignore these fundamental problems.

Despite the fact that both Whinnom and Round categorically rejected the idea that Gracisla might represent Catherine of Aragon, Haywood finds

${ }^{18}$ I have not seen the doctoral thesis of María Fernanda Aybar Ramírez ("La ficción sentimental"), who agrees with Round and argues that the work contains "un conflicto dinástico latente” (see Aybar Ramírez, "Qüestión de amor", 39 n. 8). For obvious reasons, I am skeptical about the validity of this conclusion. 
reason to revive the argument. In summarizing her case, she explains: "Now, just as there are objections to the two Juanas' status as Gracisla [sic], there are several details [...] which make Catherine of Aragon a problematic contender. I am not suggesting that Catherine is Gracisla, but rather that she is as likely a candidate as either Juana of Aragon or Juana of Naples, perhaps more so" ("The Princess", 200). ${ }^{19}$ In effect, Haywood justifies her selection of an implausible candidate for Gracisla by claiming that her choice is no worse than Whinnom's and Round's. However, this approach, based on the selective use of internal evidence, can no longer be sustained. Any historical setting for Gracisla must account for all — not just some- of the textual details. More importantly, we must stop reading the work with preconceptions inherited from earlier critics. As I have already shown, Whinnom greatly exaggerated the parallels between Catherine's wedding feasts and the text, leading Haywood to assume that this historical source was indisputable. In my opinion, this uncritical acceptance of Whinnom's ideas, most of which were only presented as working hypotheses (Dos opúsculos, xxii, xxxiv), has proved to be the largest impediment to an adequate understanding of the text.

Among the most dubious of Whinnom's conclusions is that Gracisla necessarily alludes to Henry VII's dynastic ambitions in Spain, a conjecture based solely on the narrator's observations that the fictive "rey de Inglaterra" hoped to marry Gracisla. Admittedly, the "rey de Inglaterra” plays an important part in the work; for example, he serves as one of the seven judges at the beauty pageant and praises Gracisla in their name. However, his matrimonial interest in the heroine is far from the pivotal issue Whinnom made it out to be. Like many "duques y condes" (17.84-85) and even the "rey de Castilla", the "rey de Inglaterra" is smitten by Gracisla's beauty, and his marriage proposal is merely a formulaic expression of his infatuation. ${ }^{20}$ As a matter of fact, his matrimonial intentions are incidental to the plot and have no demonstrable impact on its outcome. At the beginning of the work, for example, we are told that the "rey de Inglaterra" only goes to Paris because he wants to see the beauty contest $(6,23-24)$ - hardly the motivation one would expect of a man desperate to find a Spanish bride. The reason for this incongruity is that the portrayal of the "rey de Inglaterra" is conditioned more by his status as a powerful monarch than by his interest in marrying the heroine. Often paired

${ }^{19}$ In Haywood's nomenclature, Juana of Aragon is Juana la Loca, and Juana of Naples is Whinnom's Juana de Aragón.

${ }^{20}$ According to the narrator, "la señora Gracisla era tan conplida de tales y tantas gracias que no avía ningún príncipe ni rrey que la viese que no dessease ser súdito della” (17.76-78).

Medievalia 50, 2018, pp. 123-157 
with the "rey de Francia", he functions primarily as a symbol of royalty (17.6$7,17.69,18.2-3)$. To my mind, a far more significant clue to the identity of the "rey de Inglaterra" is his description as a "muy lindo hombre" (17.84). As I have pointed out ("A New Epithalamial Allegory", 233), Edward IV (d. 1483) was, by all contemporary accounts, the most handsome sovereign of late medieval Europe and a notorious womanizer. He was also known to Flores, who refers to him in both the Crónica incompleta (Puyol, Crónica, 299) and Triunfo de Amor (Flores, Triunfo, 143). ${ }^{21}$ Hence, the English monarch's interest in Gracisla can be understood as a form of flattery, intended to show that even a handsome foreign ruler, with a reputation as a lover, would have considered her a worthy bride. This view explains why the king's marriage proposal appears toward the end of the work and does not affect the plot.

Equally unconvincing is Whinnom's contention that the initial situation in Gracisla reflects the scandalous marriage of Charles VIII of France and Anne of Brittany in 1491. According to the text, the "rey de Francia" falls in love with Berilda, daughter of the Duke of Brittany. The royal ministers oppose their marriage because of Berilda's lower social status. Their opposition leads the king to call a beauty contest to prove that she would make a worthy bride. By contrast, the diplomatic uproar surrounding Charles VIII's marriage to the Duchess of Brittany was sparked by the French monarch's repudiation of a prior nuptial agreement with Margaret of Austria, daughter of Emperor Maximilian I. Social rank was never an issue since Anne was, in her own right, one of the most desirable brides in Europe. In addition, Charles VIII actually married Anne, unlike the "rey de Francia", whose plans to wed Berilda are left unresolved. In Gracisla, moreover, Berilda's father is alive, though Duke Francis II of Brittany died in 1488, leaving Anne the ducal title; in the text, Berilda is described only as a daughter of the "duque de Bretaña", not as sole heiress to the duchy.

Given these discrepancies, how can we justifiably conclude that the ruthlessly political marriage of Charles VIII and the Duchess of Brittany was transformed into a passionate romance between the virtuous "rey de Francia" and a daughter of the "duque de Bretaña"? Even Whinnom observed that the portrait of the fictive "rey de Francia" does not fit that of Charles VIII —or

${ }^{21}$ It is important to note that in Triunfo the lovers who fight on behalf of Amor include "el rey de Inglaterra y Talaborte con una muy armada gente, con la provincia de Bretaña crescidamente avultavan [...] del reino de Francia el conde de Tampas..." (Flores, Triunfo, 38.31-34). These characters are incorporated wholesale into Gracisla and probably represent Flores's formulaic groupings. 
his successor, Louis XII, who married Anne upon Charles's death (Dos opúsculos, xii-xiii). Yet, if we approach this matter from a different angle, ignoring the preconceived notion that this love affair has anything to do with Charles and Anne, we see that the initial situation of Gracisla is just a tissue of narrative commonplaces: a Worthy King, a Beautiful Maiden, their Forbidden Love, the Unwelcome Suitors, the Traitorous Seneschal (the royal ministers, acting collectively), and the Contest of Resolution. These literary conventions explain all the relationships and motivations at the beginning of the work — and with no nagging incongruities. As I have pointed out ("A New Epithalamial Allegory", 234-235), these conventions are simply set against a contemporary backdrop - the traditional political antagonism between Brittany and the French monarchy. Berilda, therefore, does not recall Anne of Brittany, but Helen of Troy, the archetypal pretext for a crisis of state. Contrary to Haywood's assertions, the initial situation in Gracisla is not "surely a deliberate echo of historical reality" ("The Princess", 197), but a series of topoi broadly reflecting Franco-Breton politics in the early 1470s. Any resemblance to the historical marriage of Charles VIII and the Duchess of Brittany is imperfect, inexact, and accidental, and the notion that the text postdates this union is wholly unfounded.

Additional evidence adduced by Haywood in support of her interpretation of Gracisla is of questionable relevance. She observes, for instance, that a tapestry triptych purchased by Juana la Loca in August 1502 (on display in the Escorial) depicts the coronation of the Virgin alongside the coronation of Juana and her receipt of an effigy of Felipe I; she also points out that the Cloisters tapestries portray a unicorn hunt (“The Princess", 200-201). ${ }^{22} \mathrm{Ha}$ ywood goes on to explain: "In these two tapestry series we have evidence that the two central images of Gracisla, the coronation and the death of the unicorn, were readily associated with courtship, marriage, and also possibly virginity, around the turn of the century" ("The Princess", 201). Although it is surprising to learn that the unicorn is only "possibly" associated with virginity, one might reasonably ask how either of these tapestries supports Haywood's specific contention that Gracisla is a fictional test of Catherine of Aragon's virginity. The notion that they substantiate an early sixteenth-century date for Gracisla is groundless. The association of the unicorn with virginity - and, by extension, marriage - goes much farther back than just "the turn of the

${ }^{22}$ Actually, Haywood asserts that " $[\mathrm{t}]$ hese tapestries depict hunting scenes, although also other types of celebration [sic], and in particular, there is one portraying the hunt of a unicorn" ("The Princess", 201). In fact, the latest research suggests that the panels belong to two or three separate series of unicorn allegories (Cotter, "Elusive Prey").

Medievalia 50, 2018, pp. 123-157 
century" (Shepard, The Lore, 54-59, 81-89). Indeed, the Cloisters tapestries reflect longstanding medieval traditions whose popularity can hardly be pinned down to 1502-1503 (Williamson, The Oak King, 39). More importantly, the association of the unicorn with marriage and virginity equally supports my conclusion that Gracisla was written to celebrate the betrothal of Leonor de Acuña. As I have explained ("A New Epithalamial Allegory", 248), the unicorn hunt is meant to vindicate Gracisla's triumph at the beauty contest and show that doña Leonor is worthy of marrying Pedro Álvarez Osorio, an eminent nobleman. On the basis on the unicorn episode, I described Gracisla as an epithalamial allegory. I also pointed out that, although animal images were the common property of all medieval writers, Flores often used them to clarify interpretive ambiguities in his works ("Another Work", 93-94). Like Whinnom, Haywood attempts to draw specific conclusions from conventional motifs.

Two other pieces of evidence adduced by Haywood can be dismissed as fanciful. She claims, for instance, that Catherine of Aragon ("Catalina de Aragón") had the same first name as "Kathalina Manrique", daughter of Gómez Manrique, whose death prompted the "protonotario de Lucena" to write the carta consolatoria that follows Gracisla in Gili's codex. Haywood muses: "Perhaps the association between the two texts may lie in the fact that the lady referred to as Gracisla shared a name with the deceased" ("The Princess", 201). Since the identification of Gracisla as Catherine of Aragon is only an imaginary critical construct, this speculation seems otiose. The same criticism can be made about Haywood's observation that Gracisla's eloquence recalls that of Saint Catherine ("The Princess", 194). Haywood seems to ignore the fact that female eloquence was frequently celebrated in courtly literature - and most especially in the works of Flores.

As I have previously observed, Haywood is forced to advance her argument while ignoring considerable contradictory evidence. She herself mentions the reasons why Whinnom rejected Catherine of Aragon as Gracisla's historical counterpart, but then proceeds to disregard them. She also disregards the description of the "rey de Castilla" and "rey de Francia" as "hermanos de armas" $(4.4,5.20)$, which Whinnom viewed as a reference to the 1506 Treaty of Blois (Dos opúsculos, xviii) and which I identified as an allusion to the newly negotiated truce with France in the spring of 1475 ("A New Epithalamial Allegory", 237-238). To justify overlooking these contradictions, Haywood claims that Gracisla "mediates contemporary events but is not a full roman à clef ("The Princess", 198), meaning that "we need not expect to be able to map perfectly all the details of the narrative on to historical antecedents" ("The Princess", 
192). According to this critical theory, some textual details reflect actual historical events and people, while others are just window-dressing intended to "increase [the work's] appeal" (“The Princess", 200). A vague symbol like the unicorn, for example, somehow becomes a significant clue that Gracisla speaks to the virginity of a widowed princess in 1502 , but the precise designation of the fictional heroine as the daughter of a nobleman - a direct contradiction of this interpretation - is unimportant ("The Princess", 198). A dangerous circularity underlies this reasoning. Who decides which details accurately reflect history and which just "increase [the work's] appeal"? Why is Gracisla's formulaic opening "surely a deliberate echo of historical reality" ("The Princess", 197), but the heroine's genealogy "an accidental inconsistency" ("The Princess”, 198)? Is not the reverse equally valid? Ironically, Haywood's methodology implies that if there are disparities between a text and its interpretation, the problems lie with the text. By adopting this stance, Haywood may have intended to preempt criticism of her argument, but this line of reasoning seems to undermine the validity of her own conclusions.

Even if we could accept this critical approach, Haywood's basic assumptions about Gracisla seem farfetched. Why would any writer exalt the virginity of a widowed Spanish princess by portraying her as a nobleman's unwed daughter? What is the purpose of such obfuscation? How could any contemporary audience have recognized Catherine of Aragon in this incongruous portrait? Indeed, if the author were trying to convince a wider public of Catherine's virginity, would not the point have been lost amid the distortions of the text? ${ }^{23}$ From Haywood's perspective, Gracisla would have to be seen as an artistic failure, the product of a muddled writer incapable of fictionalizing even the simplest historical detail. The work would also represent

\footnotetext{
${ }^{23}$ Haywood never addresses the issue of Gracisla's audience, which is vitally important to her argument. As J.J. Scarisbrick observes (Henry VIII, 8, 191-192), whether Catherine was a virgin or not had little immediate impact on the English decision to marry her to Henry, though it did affect the type of dispensation needed from Rome. If the marriage to Arthur had been consummated, a dispensation from the impediment of affinity was required; if not, a dispensation from the impediment of public honesty. Ironically, Catherine's insistence on nonconsummation was politically imprudent and jeoparized her legal status and her dower rights in England (Scarisbrick, Henry VIII, 194). Hence, if Gracisla's author wrote in support of such a position, he was doing more harm than good. More importantly, the negotiations for Catherine's remarriage took place at the highest diplomaticlevels. Haywood fails to explain whom Gracisla's author was trying to influence by portraying the princess as a virgin. Was he making a veiled case for a dispensation based on the impediment of public honesty instead of affinity, or was he trying to redress some perceived English insult to Catherine's honor? Whatever the case, it is hard to imagine that his work would have influenced the marriage negotiations, as Haywood implies ("The Princess", 199-200).
}

Medievalia 50, 2018, pp. 123-157 
a lost opportunity. Rather than a compelling allegory about a widowed Spanish princess who regains her right to marry the heir to the English throne, we have a tale of a Castilian maiden who, after upsetting the marriage plans of the King of France, returns home to find a husband. The author has missed the chance to create a lasting work about Catherine's plight and comment on perhaps the most momentous political issue of his day. These insurmountable problems, coupled with the others I have already discussed, lead me to reject as utterly implausible Haywood's interpretation of Gracisla.

\section{Conclusions}

154 Haywood's approach toward Gracisla illustrates the dangers of trying to make a literary work conform to a preconceived interpretation —of subordinating text to theory. In order to substantiate her hypothesis that Gracisla represents Catherine of Aragon, Haywood is forced to overinterpret vague parallels while ignoring or dismissing all incongruities. Narrative formulas like the King of England's matrimonial interest in Gracisla acquire a sweeping importance, but contradictory evidence like the heroine's genealogy is treated as an anomaly. Equally disconcerting is the fact that Haywood often sidesteps work by others when it undermines her own position. In describing Sharrer's attribution of the Tristan-Iseut letters to Flores as merely "possible [...] but not probable", she implies that his insights are simply a matter of opinion, to be accepted or rejected at will. My own attribution of Gracisla to Flores, which calls into question Haywood's most basic assumptions about the work, is ignored in favor of the counterintuitive — and unsubstantiated - view that someone else could have imitated his style. This viewpoint is ironic because, although Haywood ("The Princess", 202) acknowledges that Gracisla exhibits stylistic parallels with Flores's works and key features of his writings (the mixture of historical and fictional characters, the similarity in names, etc.), she prefers to ascribe them to someone other than Flores. But does this view really make sense? In my opinion, the attribution of Gracisla to Flores is far stronger than most medieval attributions, which are typically based on the insecure evidence of a scribal rubric. In fact, to ignore the evidence in favor of Flores's authorship of Gracisla is no less egregious than to ignore the description of Gracisla as a nobleman's daughter in order to advance the case that she represents a widowed Spanish princess.

In my previous publications on Gracisla, I have approached these matters from the opposite direction, allowing theory to serve the text. Using textual 
and other evidence, I have argued the case for Juan de Flores's authorship of the work. On the basis of archival documents, I have established a link between Flores and an aristocratic marriage whose chronology and genealogical circumstances fit all —and not just some - of the narrative details. At the same time, I have identified fatal inconsistencies in the hypotheses of Whinnom and Round and have provided alternative interpretations of their supporting evidence. Synthesizing author, historical circumstance, motivation, audience, style, and manuscript context, I have argued that Gracisla is a concrete literary response by a specific writer to a documented historical event.

\section{WORKS CITED}

Anglo, Sydney, “The London Pageants for the Reception of Katharine of Aragon: November 1501", Journal of the Warburg and Courtlaud Institutes, 26, 1963, 53-89.

Anglo, Sydney, Spectacle, Pageantry, and Early Tudor Policy, Oxford: Clarendon Press, 1969.

Aybar Ramírez, María Fernanda, "La ficción sentimental del siglo xvi”, doctoral thesis, Madrid: Universidad Complutense de Madrid, 1994.

Aybar Ramírez, María Fernanda, "Qüestión de amor": entre el arte y la propaganda, London: Department of Hispanic Studies, Queen Mary and Westfield College, 1997 (Papers of the Medieval Hispanic Research Seminar, 7).

Carrión, Manuel, "Gómez Manrique y el protonotario Lucena: dos cartas con memoria de Jorge Manrique”, Revista de Archivos, Bibliotecas y Museos, 81, $1978,565-582$.

Cotter, Holland, "Elusive Prey in a Courtly Paradise", The New York Times, Friday, July 31,1998, B31 \& 34.

DutTon, Brian (with Jineen Krogstad) (ed.), El cancionero del siglo XV (c. 13601520), Salamanca: Universidad de Salamanca, 1991 (Biblioteca Española del Siglo Xv, 3).

Flores, JuAn De, Triunfo de Amor, ed. by Antonio Gargano, Pisa: Giardini, 1981.

Flores, JuAn DE, Grimalte y Gradisa, ed. by Carmen Parrilla García, Santiago de Compostela: Universidade de Santiago de Compostela, 1988 (Monografías da Universidade de Santiago de Compostela, 140).

Foster, Donald W., “A Funeral Elegy: W[illiam] S[hakespeare]'s “Best-Speaking Witnesses", Publications of the Modern Language Association, 111, 1996, 1080-1105.

Gwara, Joseph J., "The Identity of Juan de Flores: The Evidence of the Crónica incompleta de los Reyes Católicos", Journal of Hispanic Philology, 11, 1986-1987, $103-130$ \& 203-222.

Medievalia 50, 2018, pp. 123-157 
Gwara, Joseph J., "A Study of the Works of Juan de Flores, with a Critical Edition of La historia de Grisel y Mirabella" doctoral thesis, London: University of London (Westfield College), 1988.

Gwara, Joseph J., “The Date of Juan de Flores' Triunfo de Amor”, La Corónica, 16:2, 1988, 93-96 [Corrected version in vol. 17].

GwARA, Joseph J., "A New Epithalamial Allegory by Juan de Flores: La coronación de la señora Gracisla (1475)”, Revista de Estudios Hispánicos (St. Louis), 30, 1996, 227-257.

Gwara, Joseph J., "Another Work by Juan de Flores: La coronación de la señora Gracisla", in Joseph J. Gwara and E. Michael Gerli (eds.), Studies on the Spanish Sentimental Romance (1440-1550): Redefining a Genre, London: Tamesis, 1997, 75-110.

Gwara, Joseph J., and Diane Wright, "A New Manuscript of Juan de Flores's Grisel y Mirabella: Biblioteca Apostólica Vaticana, Vat. Lat. MS 6966, ff. 68r-76v”, Journal of Hispanic Research, in press.

Haywood, Louise M., "The Princess and the Unicorn: Arthur, Prince of Wales, and Catherine of Aragon?", in Ian Macpherson and Ralph Penny (eds.), The Medieval Mind: Hispanic Studies in Honour of Alan Deyermond, London: Tamesis, 1997, 189-204.

Liss, Peggy K., Isabel the Queen: Life and Times, New York: Oxford University Press, 1992.

Mata Carrizo, Juan de (ed.), Crónica del Halconero de Juan II, Pedro Carrillo de Huete (hasta ahora inédita), Madrid: Espasa-Calpe, 1946 (Colección de Crónicas Españolas, 8).

Matulka, Barbara, The Novels of Juan de Flores and Their European Diffusion: A Study in Comparative Literature, New York: Institute of French Studies, 1931 [Rpt. Genève: Slatkine, 1974].

Norris, Frank Pelletier (ed.), "La coronica troyana": A Medieval Spanish Translation of Guido de Colonna's "Historia destructionis Troio", Chapel Hill: University of North Carolina Press, 1970 (University of North Carolina Studies in Romance Languages and Literatures, 90).

Parrilla García, Carmen, "Un cronista olvidado: Juan de Flores, autor de la Crónica incompleta de los Reyes Católicos", in Alan Deyermond and Ian Macpherson (eds.), The Age of the Catholic Monarchs, 1474-1516: Literary Studies in Memory of Keith Whinnom, Bulletin of Hispanic Studies, Special Issue, 1989, 123-133.

Patch, Howard R., The Goddess Fortuna in Mediaeval Literature, Cambridge: Harvard University Press, 1927.

Puyol, Julio (ed.), Crónica incompleta de los Reyes Católicos (1469-1476) según un manuscrito anónimo de la época, Madrid: Academia de la Historia, 1934. 
Rico, Francisco, “Unas coplas de Jorge Manrique y las fiestas de Valladolid en 1428”, Anuario de Estudios Medievales, 2, 1965, 515-524 [Rpt. in his Texto y contextos: estudios sobre la poesía española del siglo XV, Barcelona: Crítica, 1990, 169-187].

Round, Nicholas G., "Review of Keith Whinnom (ed.), Dos opúsculos isabelinos (1979)", in Medium Ævum, 50, 1982, 332-334.

SAn Pedro, Diego de, Obras completas, I: Tractado de amores de Arnalte y Lucenda; Sermón, ed. by Keith Whinnom, Madrid: Castalia, 1973 (Clásicos Castalia, 54).

San Pedro, Diego de, Obras completas, III: Poesías, ed. by Dorothy S. Severin and Keith Whinnom, Madrid: Castalia, 1979 (Clásicos Castalia, 98).

SCARISBRICK, J. J, Henry VIII, Berkeley: University of California Press, 1968.

Sharker, Harvey, "Letters in the Hispanic Prose Tristan Text[s]: Iseut's Complaint and Tristan's Reply”, Tristania, 7, 1981-1982, 3-20.

Shepard, Odell, The Lore of the Unicorn, New York: Avenel Books, 1982 [1st ed. 1930].

Stern, Charlotte, The Medieval Theater in Castile, Binghamton, NY: Medieval \& Renaissance Texts \& Studies, 1996 (Medieval \& Renaissance Texts \& Studies, 156).

Whinnom, Keith (ed.), Dos opúsculos isabelinos: "La coronación de la señora Gracisla" (BN MS. 22020) y Nicolas Núnez, "Cárcel de Amor", Exeter: University of Exeter, 1979 (Exeter Hispanic Texts, 22).

Whinnom, Keith, "Review of Juan de Flores, Triunfo de Amor, ed. by Antonio Gargano (1981)", in Bulletin of Hispanic Studies, 60, 1983, 61-62.

Williamson, John, The Oak King, the Holly King and the Unicorn: The Myths and Symbolism of the Unicorn Tapestries, New York: Harper \& Row, 1986. 
